\title{
Experimental model of glucocorticoid-induced insulin resistance ${ }^{1}$
}

\author{
Beatriz Bertolaccini Martínez ${ }^{\mathrm{I}}$, Ana Carolina Couto Pereira ${ }^{\mathrm{II}}$, Júlio Henrique MuzettiII, Fernando de Paiva Telles ${ }^{\mathrm{II}}$, Fiorita \\ Gonzáles Lopes Mundim ${ }^{I I I}$, Manoel Araújo Teixeira ${ }^{I V}$
}

DOI: http://dx.doi.org/10.1590/S0102-865020160100000001

IFull Professor, Medical Physiology Division, School of Medicine, Postgraduate Program in Sciences Applied to Health, Universidade do Vale do Sapucaí (UNIVAS), Pouso Alegre-MG, Brazil. Conception and design of the study; acquisition, analysis and interpretation of data; manuscript writing; critical revision.

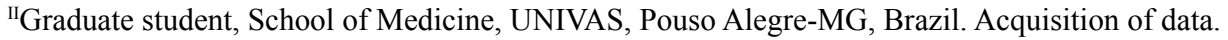

IIIAssociate Professor, Department of Pathology, School of Medicine, UNIVAS, Pouso Alegre-MG, Brazil. Histopathological examinations.

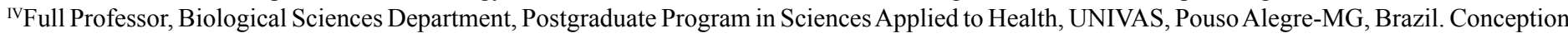
and design of the study.

\author{
ABSTRACT \\ PURPOSE: To evaluate metabolic effects in experimental model of glucocorticoid-induced insulin resistance.
}

METHODS: Twenty Wistar male rats were randomly divided into two groups, which were treated with intraperitoneally injected dexamethasone $1 \mathrm{mg} / \mathrm{Kg}$ /day for ten days consecutively (Group D; $\mathrm{n}=10$ ) and placebo (Group C; $\mathrm{n}=10$ ). The variables analyzed were: from the first to the 10th day - body weight (before and after treatment); food and water daily consumption; on the 10th day - glycemia, insulinemia, HOMA-beta and HOMA-IR. The blood samples for laboratory analysis were obtained by intracardiac puncture. Also on the $10^{\text {th }}$ day liver fragments were taken for analyzing glycogen and fattty.

RESULTS: Group D animals compared to group $\mathrm{C}$ had: weight reduction ( $\mathrm{g}),(\mathrm{D}=226.5 \pm 24.7$ vs $\mathrm{C}=295.0 \pm 25.4$; $\mathrm{p}=0.001)$; increased glycemia (mmol/1) $(\mathrm{D}=19.5 \pm 2.1$ vs $\mathrm{C}=14.2 \pm 3.1 ; \mathrm{p}=0.0001)$; diminished insulinemia (mU/l) $(\mathrm{D}=0.2 \pm 0.1$ vs $\mathrm{C}=2.0 \pm 0.4 ; \mathrm{p}=0.0001)$; reduced HOMA- $\beta(\mathrm{D}=0.2 \pm 0.1$ vs $\mathrm{C}=4.2 \pm 1.7$; $\mathrm{p}=0.0002)$; diminished HOMA-IR $(\mathrm{D}=0.2 \pm 0.1$ vs $\mathrm{C}=1.3 \pm 0.4$; $\mathrm{p}=0.0002)$. Histological examination of the liver showed that $100 \%$ of group $\mathrm{D}$ and none of group $\mathrm{C}$ had moderate fatty. $(\mathrm{p}=0.2)$.

CONCLUSION: Animals treated with glucocorticoid, in this experimental model, expressed hyperglycemia, hypoinsulinism and decreased peripheral insulin sensitivity.

Key words: Dexamethasone. Insulin Resistance. Diabetes Mellitus, Experimental. Liver Glycogen. Fatty Liver. Rats. 


\section{Introduction}

Glucocorticoids are amongst the most used drugs worldwide and they are efficient on the treatment of innumerable inflammatory and immunological diseases. Despite its therapeutic action, they induce insulin resistance in humans and can lead to steroid-induced diabetes or worsen a previously diagnosed diabetes. Insulin resistance is characterized by the reduction of the cellular ability in increasing the transportation and or using glucose as a response to insulin's action' ${ }^{1}$.

Many authors showed metabolic changes, on in vivo experimental models, after using glucocorticoids. The reduction of weight in rats $^{2,3}$. The increase on serum glucose and serum insulin ${ }^{4-6}$. Loss in muscle mass associated to liver hypertrophy ${ }^{7}$. Alteration in protein profile ${ }^{8}$ and in lipid panel ${ }^{9}$. However the efects over insulinemia are still controversial. Studies show that dexamethasone synthetic glucocorticoid reduces insulin secretion by pancreatic cells due to the oxidative stress caused on them ${ }^{10}$

${ }^{12}$. Thus this research aimed at evaluating metabolic effects on an experimental model of glucocorticoid-induced insulin resistance.

\section{Methods}

All procedures with animals have been approved by Universidade Vale do Sapucaí Ethics Committee on Animal Usage (CEUA), by $167 / 12$ protocol.

Experimental study conducted from March to July of 2015. Twenty male Wistar rats, which were 3 month-old, were utilized; they were provided by UNIVAS vivarium. Animals had free access to water and to rat's food $\left(\right.$ Nuvilab $\left.^{\circledR}\right)$ until the eve of exam collection, when they were kept on 8 hour fasting. The animals remained on isolated cages during ten consecutive days, under a temperature range from $21^{\circ}$ to $25^{\circ} \mathrm{C}$, alternating light/dark cycles.

Animals were randomized into two groups: Control $(\mathrm{C}$; $\mathrm{n}$ $=10)$ and dexamethasone $(\mathrm{D} ; \mathrm{n}=10)$. Group $\mathrm{D}$ animals received intraperitoneal dexamethasone injection (Decadron ${ }^{\circledR}$ ) $1 \mathrm{mg} / \mathrm{Kg} /$ day for ten days sequentially. Group $\mathrm{C}$ animals received intraperitoneal distilled water injection (placebo) during the same period of time. The analyzed variables were: weight (before and after treatment with placebo or dexamethasone, according to the group to which the animal belonged). Animal's food and water comsuption, from 1 st to 10th days. Glycemia, insulinemia, HOMA- (Homeostasis
Model Assessment) $\beta$ e HOMA- IR (Insulin Resistance) on 10th day. The blood sample for laboratory analysis was obtained by intracardiac puncture. Colorimetric enzymatic method was used for dosing serum glucose. Plasma insulin concentrations were determined by an automated immunoassay (Access; Beckman Instruments, Fullerton, CA). For calculating HOMA- $\beta$ e HOMA-IR equations were used:

HOMA- $\beta$ : $\quad(20 \quad x$ fasting insulin $(\mathrm{mU} / \mathrm{l})) /($ fasting glucose $(\mathrm{mmol} / \mathrm{l})-3.5)$.

HOMA-IR: fasting insulin $(\mathrm{mU} / \mathrm{l}) \mathrm{x}$ fasting glucose $(\mathrm{mmol} / \mathrm{l}) / 22.5$.

HOMA- $\beta$ evaluates the ability that pancreatic $\beta$ cells have to secrete insulin (smaller values indicate low ability); HOMA-IR indicates sensitivity to insulin (smaller values indicate bigger insulin resistance).

Liver fragments were withdrawn for assessment on glycogen and fatty. Five $\mu \mathrm{m}$-Histological cuts of hepatic tissue were stained by Hematoxylin and Eosin (HE) for quantifying fatty and were stained by periodic-acid-Schiff's reagent (PAS) for quantifying glycogen reservation. The slides were analyzed by optical microscope (Nikon E-200) on magnifications of x100 and $\mathrm{x} 400$. Slides evaluation was made by subjective analysis of presence and absence of glycogen and fatty of hepatic tissue. Lack of stain indicated "absence"; stain in $1 / 3$ of the slide indicated "mild"; stain in 2/3 of the slide indicated "moderate". Slide almost fully stained indicated "plenty" of glycogen and fatty.

Data statistical analysis was performed by BioEstat software, version 5.0. We used D'Agostino test of normality. Numeric variables with normal distribution were compared using $\mathrm{T}$ test. Nonparametric data were compared by Fisher's exact test. Comparisons between groups of animals in relation to insulin were made considering the nonparametric MannWhitney test. It has been adopted $\mathrm{p}<0.05$ for rejecting the null hypothesis.

\section{Results}

Rats treated with dexamethasone had body weight loss, on grams, (Figure 1), when compared to control group $(\mathrm{D}=226.5 \pm 24.7$ vs $\mathrm{C}=295.0 \pm 25.4 ; \mathrm{p}=0.001)$ without any reduction in providing water or food to the animals (Figures 2 and 3). 


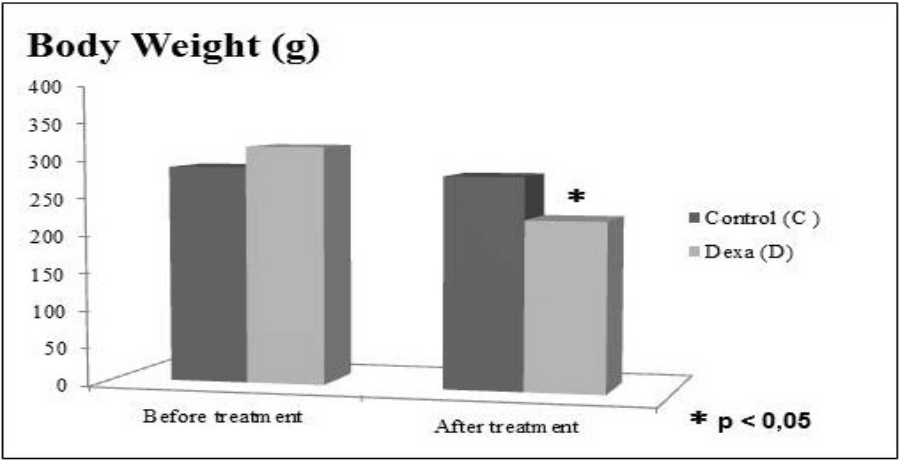

FIGURE 1 - Comparison of the Body Weight according to the group, Control $(C, n=10)$, and Dexa $(D, n=10)$, before and after treatment with dexamethasone.

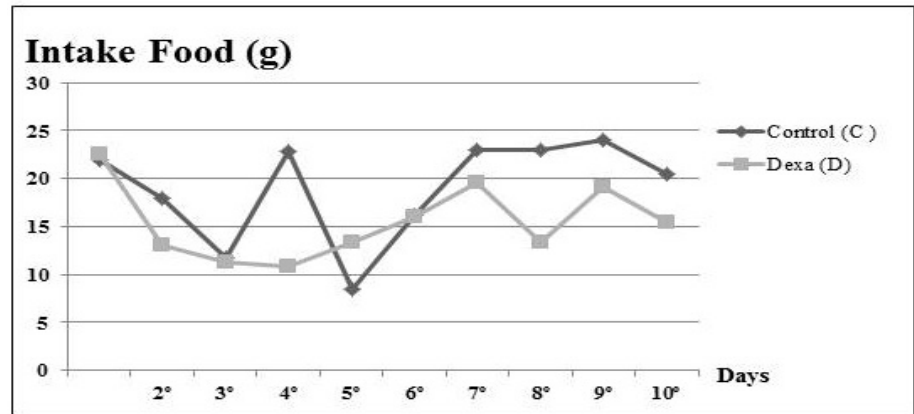

FIGURE 2 - Comparison of the Intake Water between Control (C, $\mathrm{n}=10)$ and Dexa $(\mathrm{D}, \mathrm{n}=10)$ groups.

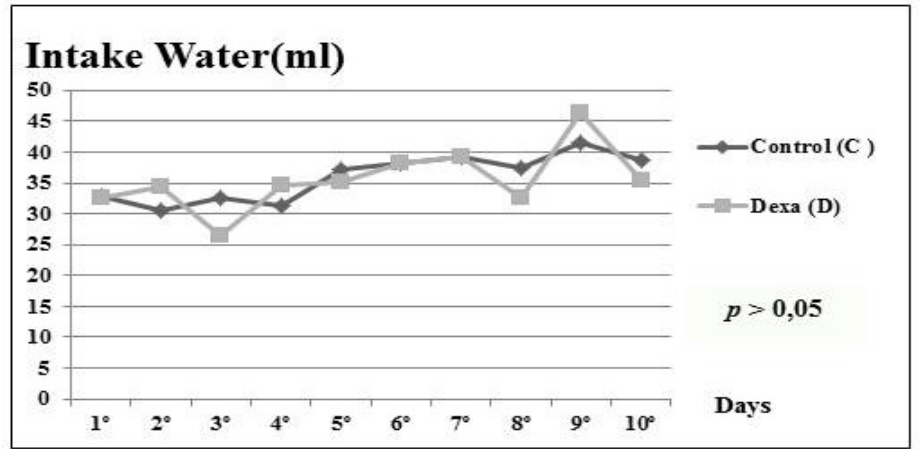

FIGURE 3 - Comparison of the Intake Water between Control $(\mathrm{C}, \mathrm{n}=10)$ and Dexa $(\mathrm{D}, \mathrm{n}=10)$ groups.

Table 1 shows that rats which received dexamethasone presented, glycemia, on $\mathrm{mmol} / \mathrm{l}$, higher than control group $(\mathrm{D}=19.5 \pm 2.1$ vs $\mathrm{C}=14.2 \pm 3.1 ; \mathrm{p}=0.0001)$; insulinemia, on $\mathrm{mU} / \mathrm{l}$, lower than control group $(\mathrm{D}=0.2 \pm 0.1$ vs $\mathrm{C}=2.0 \pm 0.4$; $\mathrm{p}=0.0001)$; HOMA- $\beta$, whose smaller values indicate diminished ability of the pancreatic $\beta$ cells to secrete insulin, it was smaller than in control's group ( $\mathrm{D}=0.2 \pm 0.1$ vs $\mathrm{C}=4.2 \pm 1.7$; $\mathrm{p}=0.0002$ ); HOMA-IR, whose smaller values express bigger insulin resistance, it was smaller than in control's group. $(\mathrm{D}=0.2 \pm 0.1$ vs $\mathrm{C}=1.3 \pm 0.4$; $\mathrm{p}=0.0002)$.
TABLE 1 - Mean and standard deviation of the bood glucose, blood insulin, HOMA $\beta$ and HOMA IR in Control (C) and Dexa (D) groups.

\begin{tabular}{cccc}
\hline VARIABLES & $\begin{array}{c}\mathbf{C} \\
(\mathbf{n = 1 0})\end{array}$ & $\begin{array}{c}\mathbf{D} \\
(\mathbf{n}=\mathbf{1 0})\end{array}$ & $\boldsymbol{p}$ \\
\hline Blood Glucose (mmol/l) & $14.2 \pm 3.1$ & $19.5 \pm 2.1$ & 0.0001 \\
Blood Insulin (mU/l) & $2.0 \pm 0.4$ & $0.2 \pm 0.1$ & 0.0002 \\
HOMA b & $4.2 \pm 1.7$ & $0.2 \pm 0.1$ & 0.0002 \\
HOMA IR & $1.3 \pm 0.4$ & $0.2 \pm 0.1$ & 0.0002 \\
\hline
\end{tabular}

HOMA $=$ Homeostasis Model Assessment

Table 2 demonstrates that $100 \%$ of the animals treated with dexamethasone and no animal from control group had moderate presence of fatty on their liver $(p=0.2)$, when submitted to histological exam.

TABLE 2 - Moderate hepatic glycogen and hepatic lipids in the group, Control (C) and Dexa (D).

\begin{tabular}{cccc}
\hline VARIABLES & C & D & \\
& $(\mathrm{n}=10)$ & $(\mathrm{n}=10)$ & $\boldsymbol{p}$ \\
\hline Hepatic glycogen $\mathbf{n}(\%)$ & $6(60)$ & $8(80)$ & 0.2 \\
Hepatic lipids $\mathbf{n}(\%)$ & 0 & $10(100)$ & 0.0002 \\
\hline
\end{tabular}

\section{Discussion}

This experimental model indicated that the use of dexamethasone - glucocorticoid - induced hyperglycemia, which is alongside with other studies, and it can be explained by insulinemia reduction and the increase to peripherical resistance to insulin (smaller HOMA-IR) ${ }^{14,15}$.

Researches made with experimental models of peripherical resistance to insulin induced by glucocorticoids have shown controversy concerning insulinemia. Serum insulin level can be increased ${ }^{16}$, unaltered ${ }^{17}$ or decreased ${ }^{18}$. The results of this study showed that there was hypoinsulinemia which, according to other researches it could have been a consequence of the decrease on pancreatic $\beta$ cells action (smaller HOMA- $\beta$ ), due to oxidative stress caused by glucocorticoids ${ }^{19}$. Other studies demonstrated that glucocorticoids have several effects on pancreatic $\beta$ cells ${ }^{20}$. Longterm exposure to glucocorticoids is associated with many diseases, including diabetes. A possible mechanism for toxicity in insulinproducing cells exposed to dexamethasone might be an increase in oxidative stress, because pancreatic $\beta$ cells are particularly vulnerable and susceptible to ROS (reactive oxygen species) 
toxicity ${ }^{21}$. Pancreatic beta cells are particularly vulnerable to ROS toxicity, due to their low antioxidant capacity and especially due to their low capacity to detoxify hydrogen peroxide, as these cells possess very low levels of catalase and glutathione peroxidase ${ }^{22}$. Probably the differences encountered must be related to dose and duration of administrating dexamethasone.

Several studies show that glucocorticoids induce peripheral insulin resistance, in vivo and in vitro ${ }^{5,8,23-26}$, by increasing hepatic glucose output and decreasing the peripheral glucose uptake. There are evidences that ROS' production plays a fundamental role on developing insulin resistance by being responsible for the smaller capture of glucose on muscle ${ }^{27}$ and on adipose tissue $^{28}$.

During quantitative analysis of liver fragments it was observed that a bigger percentage of animals treated with dexamethasone had moderate fatty amount. The increase on liver fatty has been associated to altered metabolic profiles on which insulin resistance is the prevailing characteristic ${ }^{29}$.

The reduction on body weight wasn't accompanied by decrease on feeding and drinking water. Studies indicate that injecting dexamethasone can reduce body weight without affecting food ingestion, possibly given to an increase on caloric expenditure $^{30}$. It would be interesting developing future researches to evaluate energetic metabolism in this experimental model.

\section{Conclusion}

Animals treated with glucocorticoids in this experimental model presented hyperglycemia, hypoinsulinemia and smaller peripherical sensitivity to insulin action.

\section{References}

1. Rafacho A, Roma LP, Taboga SR, Bosquero AC, Bosqueiro JR. Dexamethasone-induced insulin resistance is associated with increased connexin $36 \mathrm{mRNA}$ and protein expression in pancreatic rat islets. Can J Physiol Pharmacol. 2007 May;85(5):536-45. PMID: 17632589

2. Caldefie-Chezet F, Moinard C, Minet-Quinard R, Gachon F, Cynober L, Vasson M. Dexamethasone treatment induces longlasting hyperleptinemia and anorexia in old rats. Metabolism. 2002 Sep;50(9):1054-8. PMID: 11555838.

3. Savary I, Debras E, Dardevet D, Rambourdin F, Vasson MP, Obled C, Grizard J. Evidence for an alteration of plasma and liver proteins response to Dexamethasone in aging rats. Mech Ageing Dev Limerick. 2001 Jan;122(1):105-20. PMID: 11163627.

4. Novelli M, De Tata V, Bombara M, Lorenzini A, Masini M, Pollera M, Bergamini E, Masiello P. Insufficient adaptative capability of pancreatic endocrine function in dexamethasone-treated ageing rats. J Endocrinol. 1999 Sep;162(3):425-32. PMID: 10467234.

5. Barbera M, Fierabracci V, Novelli M, Bombara M, Masiello P, Bergamini E, De Tata V. Dexamethasone-induced insulin resistance and pancreatic adaptative response in ageing rats are not modified by oral vanadyl sulfate treatment. Eur J Endocrinol. 2001 Dec;145(6):799-806. doi: 10.1530/eje.0.1450799.

6. Roma LP, Souza KLA, Carneiro EM, Boschero AC, Bosqueiro JR. Pancreatic islets from dexamethasone-treated rats show alterations in global gene expression and mitochondrial pathways. Gen Physiol Biophys. 2012 Mar;31(1):65-76. PMID: 22447832.

7. Savary I, Debras E, Dardevet D, Sornet C, Capitan P, Prugnaud P, Patureau Mirand P, Grizard J. Effect of glucocorticoid excess on skeletal muscle and heart protein synthesis in adult and old rats. $\mathrm{Br}$ J Nutr Cambridge. 1998 Mar;79(3):297-304. PMID: 9577308.

8. Ruzzin J, Wagman AS, Jensen J. Glucocorticoid-induced insulin resistance in skeletal muscles: defects in insulin signaling and the effects of a selective glycogen synthase kinase-3 inhibitor. Diabetologia. 2005;48(10):2119-30. doi: 10.1007/s00125-0051886-0.

9. Holness M J, Smith MD, Greenwood GK, Sugden MC. Interactive influences of peroxissome proliferator-activated receptor activation and glucocorticoids on pancreatic beta cell compensation in insulin resistance induced by dietary saturated fat in the rat. Diabetologia. 2005 Oct;48(10):2062-8. PMID: 16132960.

10. Lenzen S, Drinkgern J, Tiedge M. Low antioxidant enzyme gene expression in pancreatic islets compared with various other mouse tissues. Free Radic Biol Med. 1996 Jan;20(3):463-6. doi: 10.1016/0891-5849(96)02051-5.

11. Li N, Frigerio F, Maechler P. The sensitivity of pancreatic beta-cells to mitochondrial injuries triggered by lipotoxicity and oxidative stress. Biochem Soc Trans. 2008 Oct;36(5):930-4. doi: 10.1042/ BST0360930.

12. Souza KL, Gurgul-Convey E, Elsner M, Lenzen S. Interaction between pro-inflammatory and anti-inflammatory cytokines in insulin-producing cells. J Endocrinol. 2008 Apr;197(1):139-50. PMID: 18372240.

13. Matthews Dr, Hosker JP, Rudenski AS, Naylor BA, Treacher DF, Turner RC. Homeostasis model assessment: insulin resistance and beta-cell function from fasting plasma glucose and insulin concentrations in man. Diabetologia. 1985 Jul;28(7):412-9. PMID: 3899825

14. Ogawa A, Johnson JH, Ohneda M, McAllister CT, Inman L, Alam $\mathrm{T}$, Unger RH. Roles of insulin resistance and b -cell dysfunction in dexamethasone-induced diabetes. J Clin Invest. 1992 Aug;90(2):497504. doi: 10.1172/JCI115886. PMID:1644920.

15. Toriumi C, Imai K. Altered expresion of insulins I and II and their mRNAs in the islets of Langerhans in dexamethasone-induced diabetic rats. Biomed Chromatogr. 2003 Jan;17(1):26-32. doi: 10.1002/bmc. 212 .

16. Wang ZL, Bennet WM, Wang RM, Ghatei MA, Bloom SR. Evidence of a paracrine role of neuropeptide $\mathrm{Y}$ in the regulation of insulin release from pancreatic islets of normal and dexamethasonetreated rats. Endocrinology. 1994 Jul;135(1):200-6. doi: 10.1210/ en.135.1.200.

17. O'Brien TD, Westermark P, Johnson KH. Islet amyloid polypeptide and insulin secretion from isolated perfused pancreas of fed, fasted, glucose-treated, and dexamethasone-treated rats. Diabetes. 1991 Dec;40(12):1701-6. doi: 10.2337/diabetes.40.12.1701.

18. Jeong IK, Oh SH, Kim BJ, Chung JH, Min YK, Lee MS. The effects of dexamethasone on insulin release and biosynthesis are dependent on the dose and duration of treatment. Diabetes Res Clin Pract. 2001 Mar;51(3):163-71. doi: 10.1016/S0168-8227(00)00229-1.

19. Roma LP, Bosqueiro JR, Cunha DA, Carneiro EM, Gurgul-Convey E, Lenzen S, Bosquero AC, Souza KLA. Protection of insulinproducing cells against toxicity of dexamethasone by catalase overexpression. Free Radical Biol Med. 2009 Nov;47(10):1386-93. PMID: 19698781. 
20. Lenzen S, Bailey CJ. Thyroid hormones, gonadal and adrenocortical steroids and the function of the islets of Langerhans. Endocr Rev. 1984 Summer;5(3):411-34. PMID: 6381036.

21. Buckingham JC. Glucocorticoids: exemplars of multi-tasking. Br J Pharmacol. 2006 Jan;147 (Suppl. 1):S258-68. PMID: 16402112.

22. Lenzen S. Oxidative stress: the vulnerable beta-cell. Biochem Soc Trans. 2008 Jun;36(3):343-7. doi: 10.1042/BST0360343.

23. Burén J, Liu HX, Jensen J, Eriksson JW. Dexamethasone impairs insulin signalling and glucose transport by depletion of insulin receptor substrate-1, phosphatidylinositol 3-kinase and protein kinase B in primary cultured rat adipocytes. Eur J Endocrinol. 2002 Mar;146(3):419-29. doi: 10.1530/eje.0.1460419.

24. Nicod N, Giusti V, Besse C, Tappy L. Metabolic adaptations to dexamethasone-induced insulin resistance in healthy volunteers. Obes Res. 2003 May;11(5):625-31. PMID: 12740452.

25. Saad MJ, Folli F, Kahn JA, Kahn CR. Modulation of insulin receptor, insulin receptor substrate-1 (IRS1) and phosphatidylinositol 3-kinase in liver and in muscle of dexamethasone treated rats. J Clin Invest. 1993 Oct;92(4):2065-72. PMID: 7691892.

26. Severino C, Brizzi P, Solinas A, Secchi G, Maioli M, Tonolo G. Lowdose dexamethasone in the rat: a model to study insulin resistance. Am J Physiol Endocrinol Metab. 2002 Aug;283(2):E367-73. PMID: 12110544

27. Fridlyand LE, Philipson LH. Reactive species and early manifestation of insulin resistance in type 2 diabetes. Diabetes Obes Metab. 2006 Mar;8(2):136-45. doi: 10.1111/j.1463-1326.2005.00496.x.

28. Houstis N, Rosen ED, Lander ES. Reactive oxygen species have a causal role in multiple forms of insulin resistance. Nature. 2006 Apr;440(7086):944-8. doi: 10.1038/nature04634.

29. Marchesini G, Brizi M, Blanchi G, Tomassetti S, Bugianesi E, Lenzi M, Mccullough AJ, Melchionda N. Nonalcaholic fatty liver disease: a feature of metabolic syndrome. Diabetes. 2001 Aug;50(8):184450. PMID: 11473047.
30. Franco-Colin M, Tellez-Lopez AM, Quevedo-Corona L, Racotta L. Effects of long-term high-sucrose and dexameyhasone on fat depots, liver fat, and lipid fuel fluxes through the retroperitoneal adipose tissue splanchnic area in rats. Metabolism. 2000 Oct;49(10):128994. PMID: 11079818

\section{Acknowledgements}

To Ivan Lúcio de Melo and José Lopes Chave Neto for technical assistance.

\section{Correspondence:}

Beatriz Bertolaccini Martínez

Avenida Coronel Alfredo Custódio de Paula, 320 / Campus Central 37550-000 Pouso Alegre - MG Brasil

Tel.: (55 35)3449-8772

beatrizbbmartinez@gmail.com

Received: Jun 21, 2016

Review: Aug 19, 2016

Accepted: Sep 18, 2016

Conflict of interest: none

Financial source: FAPEMIG

${ }^{1}$ Research performed at Experimental Surgery Laboratory, Medical School, Universidade do Vale do Sapucaí (UNIVAS), Pouso Alegre-MG, Brazil. 